\title{
Experimental model for low level laser therapy on ischemic random skin flap in rats ${ }^{1}$
}

\author{
Modelo experimental para laserterapia de baixa intensidade \\ em retalho cutâneo randômico isquêmico em ratos
}

\author{
Rodrigo Paschoal Prado², Richard Eloin Liebano ${ }^{3}$, Bernardo Hochman ${ }^{3}$, Carlos Eduardo Pinfildi ${ }^{2}$ Lydia Masako Ferreira $^{4}$ \\ 1. This study is part of thesis presented, Post-Graduation Program in Plastic Surgery, Master degree, Federal University of São Paulo \\ (UNIFESP). Brazil. \\ 2. Master in Basic Sciences in Plastic Surgery, UNIFESP. Brazil. \\ 3. PhD, Plastic Surgery, UNIFESP. Brazil. \\ 4. Head, Full Professor, Plastic Surgery Division, Surgery Department, Coordinator of Post-Graduation Program in Reconstructive Plastic \\ Surgery, UNIFESP. Brazil.
}

\begin{abstract}
Purpose: To develop an experimental model to be used in the study of low level Laser therapy on viability of random skin flap in rats. Methods: The sample was 24 Wistar-EPM rats. The random skin flap measured $10 \mathrm{x} 4 \mathrm{~cm}$ and a plastic sheet was interposed between the flap and donor site. Group 1 (control) underwent sham irradiation with diode laser (830 nm). Group 2 was submitted to laser irradiation with diode laser $(830 \mathrm{~nm})$. The animals were submitted to Laser therapy with $36 \mathrm{~J} / \mathrm{cm}^{2}$ energy density (72 seconds) immediately after the surgery and on the four subsequent days. The probe was usually held in contact with the skin flap surface on a point at $2.5 \mathrm{~cm}$ cranial from the flap base. On the seventh postoperative day, the percentage of necrotic area was measured and calculated. Results: Group 1 reached an average necrotic area of 48.86\%, Group $2-23.14 \%$. After the statistic analysis, compared with the control group, Group 2 showed a statistically significant increase in survival area $(\mathrm{p}<0.001)$.Conclusion: The experimental model proved to be reliable to be used in the study of effects of low level laser therapy in random skin flap in rats.
\end{abstract}

Key words: Laser Therapy, Low-Level. Surgical Flaps. Necrosis. Rats.

\section{RESUMO}

Objetivo: Propor o desenvolvimento de um modelo experimental para verificar o efeito da laserterapia de baixa intensidade na viabilidade do retalho cutâneo randômico em ratos. Métodos: A amostra constituiu-se de 24 ratos, da linhagem WistarEPM. O retalho cutâneo randômico foi realizado com dimensões de 10x4 cm e uma barreira plástica foi interposta entre o mesmo e o leito doador. O Grupo 1 (controle), foi submetido a uma simulação de tratamento com a irradiação laser de diodo $(830 \mathrm{~nm})$. O Grupo 2 foi submetido à irradiação laser de diodo $(830 \mathrm{~nm})$. Os animais foram submetidos a terapia a laser com densidade de energia de $36 \mathrm{~J} / \mathrm{cm} 2$ (72 segundos) imediatamente após a operação e nos outros quatros dias subseqüentes. A caneta do laser foi posicionada a 90 graus em contato com o retalho cutâneo em um ponto a 2,5 cm da base cranial do retalho. No sétimo dia pós-operatório foram calculadas as porcentagens da área de necrose. Resultados: O Grupo 1 apresentou média da área de necrose de 48,86\% e o Grupo 2 -23,14\%. Após a análise estatística, os resultados mostraram que o Grupo 2 foi mais eficaz, quando comparado ao controle $(\mathrm{p}<0,001)$. Conclusão: O modelo experimental mostrou-se factível para estudos dos efeitos da terapia a laser de baixa intensidade em retalho cutâneo randômico em ratos.

Descritores: Terapia a Laser de Baixa Intensidade. Retalhos Cirúrgicos. Necrose. Ratos.

\section{Introduction}

The skin flap is the most frequent surgical procedure used in the plastic and reconstructive surgery. The main and most feared complication responsible for failure of procedures with skin flaps is ischemia. If it is durable it evolves to tissue necrosis, so causing an undesirable failure of the proposed treatment. In this case, new surgical interventions are needed, so increasing the return time to daily activities. ${ }^{1-3}$
However, several investigators have researched on both mechanisms and some possible drugs which help the viability of skin flap, by improving the blood flow. ${ }^{4-7}$ Moreover, many of these drugs present undesirable side effects, making their use unviable in clinical practice. ${ }^{1.2 .4-6}$

Therefore, a new research field using nonpharmacological agents, such as low level laser therapy, has emerged as an important agent for improving both microcirculation and neoangiogenesis ${ }^{8-14}$, to be studied as a possible method in the treatment of ischemic skin flaps. 
Due to the characteristics of this kind of treatment, application facility, associated with the methodological deficiency of few experimental studies performed in animals on parameters and operation procedure, the purpose of this study was to develop an experimental model to be used in the study of low level Laser therapy on viability of random skin flap in rats.

\section{Methods}

The study was approved by Commission of Ethics in Research of Federal University of São Paulo[UNIFESP] going in the current apt legislation.

Twenty four rats were used (Rattus norvegicuns: var. albinus, Rodentia, Mammalia), lineage Wistar EPM -1, adult male rats, weighing 260 to $320 \mathrm{~g}$ and randomly divided into two groups with 12 rats each.

\section{Laser}

The diode laser equipment used in this study was Ibramed ${ }^{\circledR}$ Equipamentos Médicos with $830 \mathrm{~nm}$ wavelength, $36 \mathrm{~J} / \mathrm{cm}^{2}$ energy density, power $30 \mathrm{~mW}$ and $0.07 \mathrm{~cm}$ beam diameter.

\section{Operation technique}

All rats were anesthetized with tiletamine hydrochloride and zolazepam hydrochloride $(50 \mathrm{mg} / \mathrm{g}$ ) intraperitoneally during operation and during laser therapy sessions. After anesthesia induction, the rats were positioned on a flat surface with members extended and a digital trichotomy on their backs was performed.

Then, the planning of the flap through a plastic mould [film F-1 (poliester + poliethilene)] was performed, cut out in pattern sizes $(10 \times 4 \mathrm{~cm})$ on animals backs, taking as limits the inferior angles of the scapulae and the superior bones of pelvis (Figure 1). The random skin flap with cranial base was cut by scalpel and elevated through deep fascia, including superficial fascia, panniculus carnosus, the subcutaneous tissue and $\operatorname{skin}^{15}$ (Figure 2). After flap elevation a plastic barrier (film F1), with same dimensions $(10 \times 4 \mathrm{~cm})$ was placed between the flap and its donor site ${ }^{16,17}$, and the suture was made with simple nylon 4-0 stitches (Figure 3) $^{2,3}$

After surgical procedure, Group 1 was kept anesthetized and subjected to sham irradiation with diode laser $(830 \mathrm{~nm})$ for 72 seconds and, for the four subsequent days, in determined time, with $36 \mathrm{~J} / \mathrm{cm}^{2}$ energy density.

Group 2 received laser treatment as follows: One point at $2.5 \mathrm{~cm}$ cranial from the flap base on each flap was marked and used the punctual contact technique (Figure 4). To ensure the uniformity and to ease making the markings, a 10 $\mathrm{x} 4 \mathrm{~cm}$ plastic film with one point fenestration was applied (Figure 5). The point was irradiated for 72 seconds. Laser treatment was daily performed for 5 days. After the laser therapy sessions, the animals went back to their respective cage and received commercial ration and water ad libitum.

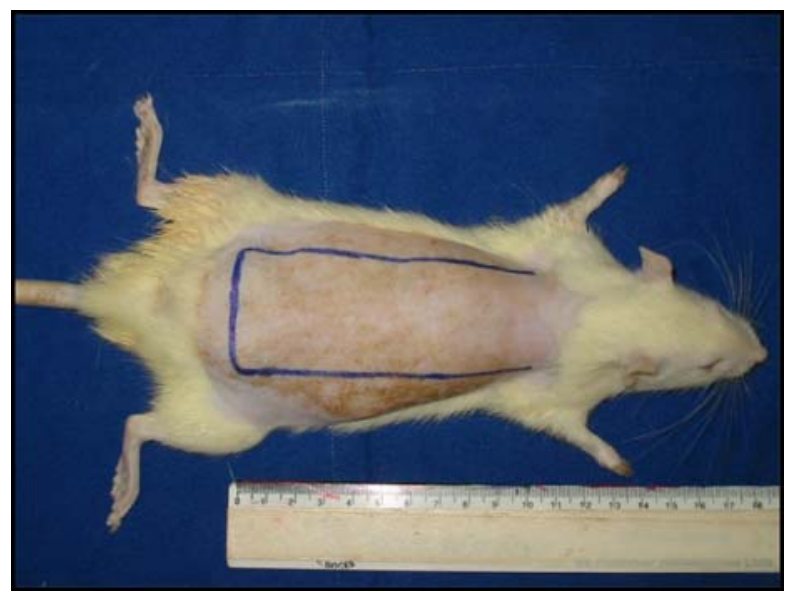

FIGURE 1 - Planning flap in pattern sizes

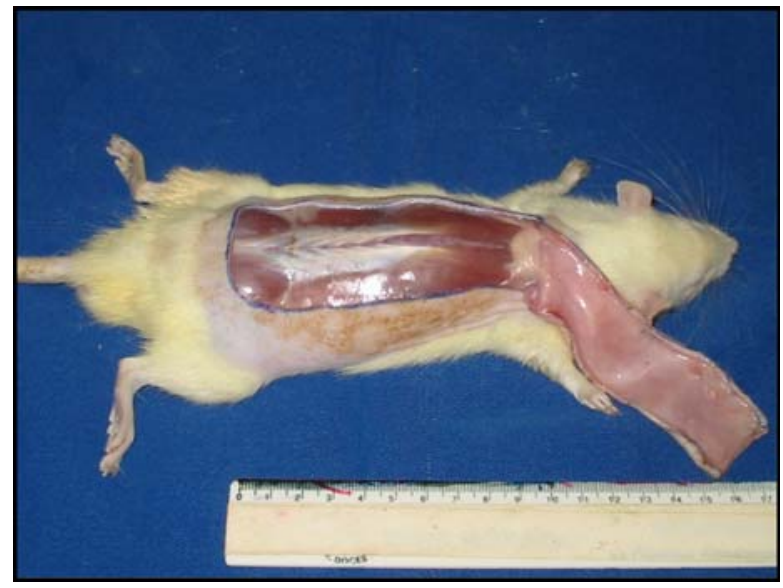

FIGURE 2 - Random skin flap raised

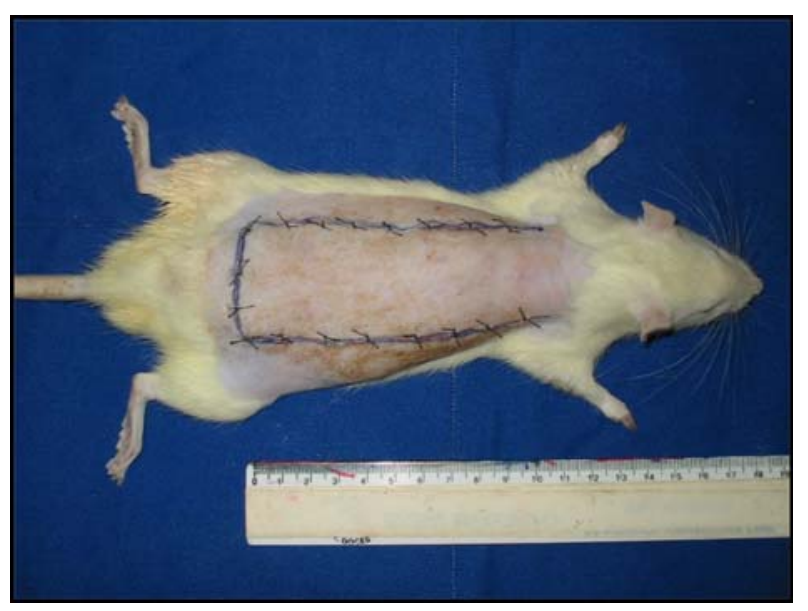

FIGURE 3 - Suture with 4-0 nylon stitches after the flap being raised and a plastic barrier interpositioned. 


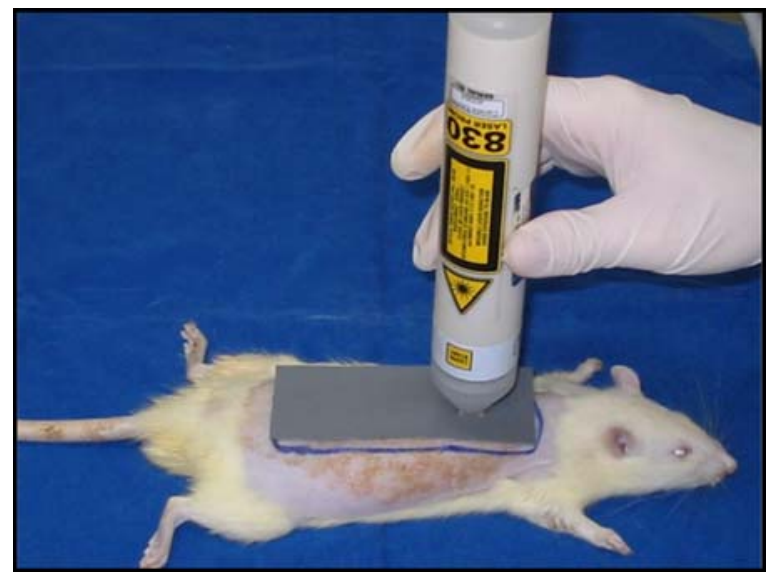

FIGURE 4 - Punctual contact technique

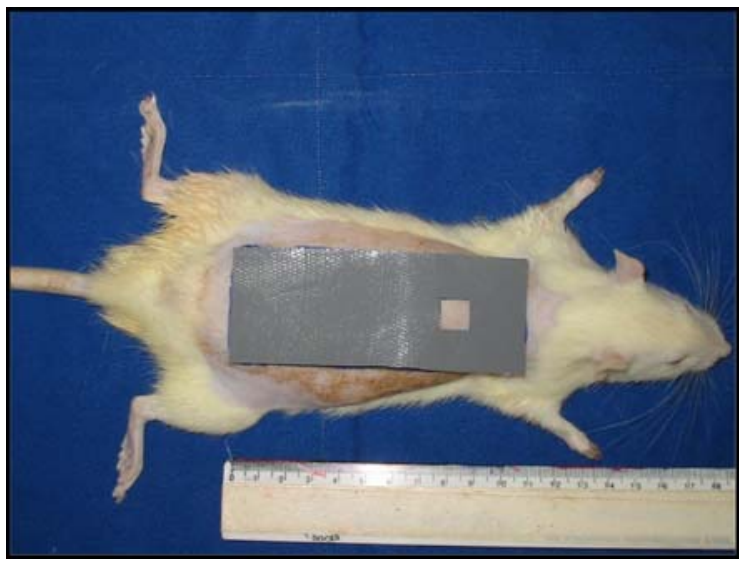

FIGURE 5 - Plastic template on the skin flap with the demarkation of the point

Method for estimating percentage of necrotic area in distal portion of flaps

The percentage of skin flap necrosis area was calculated on the seventh postoperative day through the paper template method. The limit between viable tissue characterized by soft skin, reddish, warm and haired, and necrotic tissue (stiff, dark, cool and hairless skin) was demarcated on the animals ${ }^{18}$.

A mold of entire flap and the necrotic area was drawn and cut in transparent paper, being checked in a precision balance (+/- 0.001g error). After that, the following equation was used:

$$
\begin{gathered}
\text { area of the flap } \\
\text { rentage of necrosis }
\end{gathered}=\frac{\text { of flap necrosis }}{\begin{array}{c}
\text { weight of paper template } \\
\text { of total area of flap }
\end{array}} \times 100
$$

\section{Results}

The percentages of necrotic area among rats were: Group 1 (48.86\% SD 3.76) and Group 2 (23.14\% SD 5.43)(Table 1). The ANOVA test was used to analyze the variance and Bonferroni‘s correction was applied to compare groups.
TABLE 1 - Percentage of necrotic area in the $7^{\text {th }}$ posoperative day

\begin{tabular}{ccc}
\hline Animal & Group 1 & Group 2 \\
\hline $\mathbf{0 1}$ & 57.10 & 21.03 \\
$\mathbf{0 2}$ & 48.27 & 30.96 \\
$\mathbf{0 3}$ & 47.12 & 33.73 \\
$\mathbf{0 4}$ & 50.42 & 25.21 \\
$\mathbf{0 5}$ & 45.21 & 23.24 \\
$\mathbf{0 6}$ & 46.87 & 28.94 \\
$\mathbf{0 7}$ & 48.69 & 19.75 \\
$\mathbf{0 8}$ & 42.76 & 18.31 \\
$\mathbf{0 9}$ & 51.95 & 20.02 \\
$\mathbf{1 0}$ & 49.14 & 17.10 \\
\hline $\mathbf{1 1}$ & 46.47 & 21.20 \\
$\mathbf{1 2}$ & 52.33 & 18.25 \\
\hline Average & $\mathbf{4 8 . 8 6}$ & $\mathbf{2 3 . 1 4}$ \\
\hline \multicolumn{3}{|c}{} \\
\hline
\end{tabular}

Compared with the control group, Group 2 showed a statistically significant increase in the survival area $(\mathrm{p}<0.001)$. (Figures 6 and 7).

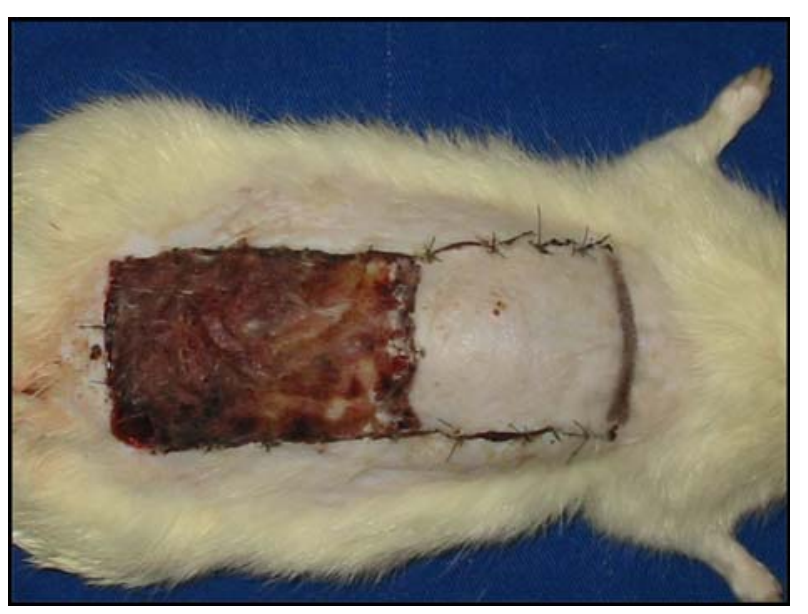

FIGURE 6 - Necrotic area - control group after seven days

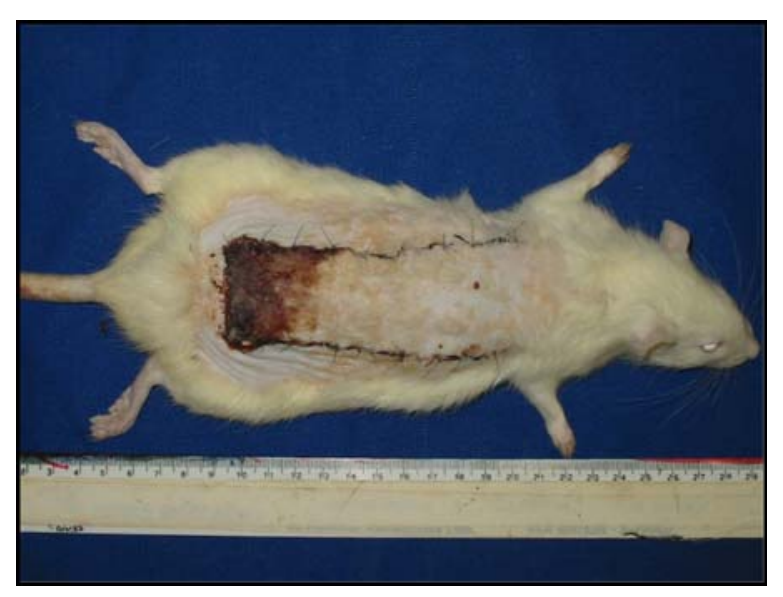

FIGURE 7 - Necrotic area - laser irradiation group after seven days of therapy 


\section{Discussion}

The augmentation of skin flap survival has been of great concern for plastic surgeons. In general, the delay procedure is said to be the most effective method of increasing survival area-12. However, the delay procedure requires repeated operations and prolonged hospitalization.

Many experiments attempting to increase flap survival by pharmacological methods have been reported ${ }^{4,6}$. However, the effects of drugs are usually transient and unstable. Low-power lasers have been reported to have biostimulating effects. Due to the important circulation effects found as neoangiogenesis, the increasing of blood flow and fibroblasts proliferation, the research on low laser therapy in skin flaps was started ${ }^{2,3,9}$.

In the present study, a model of skin flaps with measurements of $10 \times 4 \mathrm{~cm}$ developing ischemia in their distal portion was used ${ }^{15}$. Plastic film was interposed between the flap and the donor site to avoid the revascularization of the flap through donor site vessels, thus assuring homogeneous ischemia and necrosis conditions ${ }^{16,17}$.

The paper template method was selected to evaluate the percentage of necrotic area because it is simple and quick, and only requires transparent paper and an accurate scale $^{18}$.

The energy density used was $36 \mathrm{~J} / \mathrm{cm}^{2}$ based on the research carried out by Kubota and Ohshiro ${ }^{11}$ who observed, using the Doppler laser, a significant increase of vascular perfusion when using this dose.

In this study, the technique used was the punctual technique with contact, since this one is more efficient due to its small energy dispersion ${ }^{9-11}$. The probe was held in contact with the skin flap surface on a point at $2.5 \mathrm{~cm}$ cranial from the flap base. The irradiation lasted 72 seconds.

The results of this study showed that the difference between the experimental group (Group 2) and the control group (Group 1) were statistically significant. Group 2 was efficient for increasing the random skin flap viability in rats, maybe due to the enhancement of vascular perfusion. Moreover, low-level thermal effects cannot be excluded as a potential mechanism to increase vascular perfusion, since Stadler et al. ${ }^{19}$ showed a thermal increase in rats, and thermal effects of irradiation are unlikely to explain the LLLT effect, but because they used infrared $830 \mathrm{~nm}$ laser, the skin color should be considered, particularly at higher flows.

Although the purpose of this study was not to measure the blood flow of the skin flap, it may suggest that the increase of skin flap viability of the experimental group may increase vascular perfusion.

\section{Conclusion}

The experimental model proved to be useful in the study of effects of low level laser therapy on viability of random skin flap in rats.

\section{References}

1. Kerrigan CL. Skin flap failure: pathophysiology. Plast Reconstr Surg. 1983; 72: 766-77.

2. Liebano RE, Ferreira LM, Sabino Neto M. Transcutaneous electrical nerve stimulation on viability of random skin flap in rats. Can J Plast Surg. 2002; 10: 151-4.

3. Liebano RE, Ferreira LM, Sabino Neto M. Experimental model of transcutaneous electrical nerve stimulation on ischemic random skin flap in rats. Acta Cir Bras. 2003; 18, Special Edition. Available on URL: http://www.scielo.br/acb.

4. Duarte SI, Gomes HFC, Ferreira LM. Effect of dimethyl sulphoxide on necrosis of skin flaps in rats. Can J Plast Surg. 1998; 6: 93-7.

5. Guerardini G, Lundeberg T, Cui J, Eriksson SV, Trubek S, Linderoth B. Spinal cord stimulation improves survival in ischemic skin flaps: an experimental study of the possible mediation by calcitonin gene-related peptide. Plast Reconstr Surg. 1999; 103: 1221-8.

6. Davis ER, Wachholz JH, Jassir D, Perlyn CA, Agrama MH. Comparison of topical anti-ischemic agents in salvage of failing random-pattern skin flaps in rats. Arch Facial Plast Surg. 1999; 1: 27-32.

7. Salmi AM, Hong C, Futrell JW. Preoperative cooling and warming of the donor site increase survival of skin flaps by the mechanism of ischemic preconditioning: an experimental study in rats. Scand J Plast Reconstr Hand Surg. 1999; 33: 163-7.

8. Stranc MF, Sowa MG, Abdulrauf B, Mantsch HH. Assessment of tissue viability using near-infrared spectroscopy. Br J Plast Surg. 1998; 51: 210-17.

9. Kami T, Yoshimura Y, Nakajima T, Ohshiro T, Fujino T. Effects of Low-Power Diode Lasers on Flap Survival. Ann Plast Surg. 1985; 14: 278-83.

10. Smith RJ. The effect of Low-Energy Laser on Skin-Flap Survival in the Rat and Porcine Animal Models. Plast Reconstr Surg. 1992; 89: 306-10.

11. Kubota J, Oshiro T. The effects of diode laser LLLT on flap survival: measurement of flap microcirculation with laser speckle flowmetry. Laser Ther. 1996; 8: 241-6.

12. Schindl A, Schindl M, Schindl L, Jureka W, Honigsmann $\mathrm{H}$, Breier F. Increased dermal angiogenesis after low intensity laser therapy for chronic radiation ulcer determined by a Video measuring system. J Am Acad Dermatol. 1999; 40: 481-4.

13. Amir A, Solomon AS, Giler S, Cordoba M, Hauben DJ. The influence of helium-neon laser irradiation on the viability of skin flaps in the rat. Br J Plast Surg. 2000; 53: 58-62.

14. Low J, Reed A. Eletroterapia explicada: princípios e prática. 3ed. São Paulo: Manole; 2001.

15. McFarlane RM, DeYoung G, Henry RA. The design of a pedicle flap in the rat to study necrosis and its prevention. Plast Reconstr Surg. 1965; 35: 177-82.

16. Ugland O. Flaps and flap necrosis. Acta Chir Scand. 1966; 131: 408-12. 
17. Kaufman T, Angel MF, Eichenlaub EH, Levin M, Hurwitz DJ, Futrell JW. The salutary effects of the bed on the survival of experimental flaps. Ann. Plast Surg. 1985; 14: 64-73.

18. Sasaki GH, Pang CY. Hemodinamics and viability of acute neurovascular island skin flap in rats. Plast Reconstr Surg. 1980; 65: 152-8.
19. Stadler I, Lanzafame RJ, Oskoui P, Zhang RY, Coleman J, Whittaker M. Alteration of skin temperature during lowlevel laser irradiation at $830 \mathrm{~nm}$ in a mouse model. Photomed Laser Surg. 2004;22:227-31.

\section{Correspondence:}

Rodrigo Paschoal Prado

Plastic Surgery Division - Federal University of São Paulo

Rua Napoleão de Barros, 715/4 andar

04024-900 São Paulo - SP Brazil

Phone:(5511)5576-4118

paschoalrp@hotmail.com

sandra.dcir@epm.br
Conflict of interest: none Financial source: none

Received: January 12, 2006

Review: February 14, 2006

Accepted: March 15, 2006

\section{How to cite this article:}

Prado RP, Liebano RE, Hochman B, Pinfildi CE, Ferreira LM. Experimental model for low level laser therapy on ischemic random skin flap in rats. Acta Cir Bras. [serial on the Internet] 2006 July-Aug;21(4). Available from URL: http://www.scielo.br/acb 